\title{
Implementasi Pendidikan Akhlak Mulia di SMA Setia Dharma Pekanbaru
}

\author{
DEVI ARISANTI \\ Fakultas Tarbiyah dan Keguruan UIN Suska Riau \\ Jl. HR. Soebrantas km. 15 Tampan Pekanbaru \\ e-mail: deviarisanty@gmail.com
}

\begin{abstract}
This study aims to describe and analyze the implementation of noble moral education and its supporting and inhibiting factors. The research approach is a qualitative study conducted in SMA Setia Dharma Pekanbaru with the subject of principal and teacher research. For data collection, interviews, observations, documentation and Focus Roup Discussion were conducted. Techniques of data analysis of this research is data reduction, data display and data verification then draw conclusions from the data that has been presented gradually to be the research findings. This paper concludes that: principals and teachers have attempted to implement noble moral education to learners from exemplary education, habituation, attention, giving advice, and educational punishment. Supporting factors of school principals who seek to disseminate school vision and mission to the school community and cooperation between school principals and other components. Inhibiting factors are still inadequate for musholla and fund allocation for religious activities.
\end{abstract}

Keywords: Implementation, Education, Noble Character

Abstrak: Penelitian ini bertujuan untuk mendeskripsikan dan menganalisis implementasi pendidikan akhlak Mulia serta faktor pendukung dan penghambatnya. Pendekatan penelitian adalah kualitataif yang dilaksanakan di SMA Setia Dharma Pekanbaru dengan subjek penelitian kepala sekolah dan guru. Untuk pengumpulan data dilakukan wawancara, observasi, dokumentasi dan Focus roup Discussion. Tehnik analisis data penelitian ini adalah reduksi data, display data dan verifikasi data kemudian menarik kesimpulan dari data-data yang telah disajikan secara bertahap hingga menjadi temuan penelitian. Tulisan ini menyimpulkan bahwa kepala sekolah dan para guru sudah berupaya mengimplementasikan pendidikan akhlak mulia kepada para peserta didik baik dari aspek pendidikan keteladanan, pembiasaan, perhatian, pemberian nasehat, dan hukuman yang mendidik. Faktor pendukung dari kepala sekolah yang berupaya mensosialisasikan visi dan misi sekolah kepada warga sekolah dan adanya kerjasama antara kepala sekolah dan komponen lainnya. Faktor penghambat masih kurang memadainya musholla dan alokasi dana untuk kegiatan keagamaan.

Kata kunci: Implementasi, Pendidikan, Akhlak Mulia 


\section{PENDAHULUAN}

Peningkatan mutu pendidikan di Indonesia terus diupayakan oleh pemerintah dan berbagai pihak yang terkait. Keberhasilan dalam bidang pendidikan pada hakikatnya tidaklah hanya dilihat dari tingkat kelulusan yang tinggi, namun juga dlihat dari segi keberhasilan dalam pendidikan akhlak mulia. Untuk itulah pemerintah bahkan menjelaskannya di dalam UU Sisdiknas Nasional Bab I Ketentuan Umum, Pasal I yang berbunyi "Pendidikan adalah usaha sadar dan terencana untuk mewujudkan suasana belajar dan proses pembelajaran agar peserta didik secara aktif mengembangkan potensi dirinya untuk memiliki kekuatan spritual keagamaan, pengendalian diri, kepribadian, kecerdasan, akhlak mulia, serta keterampilan yang diperlukan dirinya, masyarakat, bangsa dan negara" (UU SISDIKNAS Mo. 20 Tahun 2003)

Pengaruh pendidikan akan tampak tidak hanya dari segi intelektual seseorang namun juga dari segi akhlak mulia. Ketakwaan peserta didik kepada Allah SWT terimplementasi dari akhlak mulia yang diamalkannya.

Allah SWT berfirman dalam QS. Al-Qalam/ 68: 4;

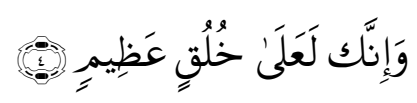

Artinya : "Dan Sesungguhnya kamu benarbenar berbudi pekerti yang luhur." (DEPAG, 2002: 826).

Pendidikan akhlak menjadi suatu keniscayaan di zaman yang sudah menunjukkan kemajuan ini. Perubahan zaman tidak berarti bahwa kebutuhan manusia akan pendidikan akhlak menjadi berkurang. Pendidikan akhlak menjadi tanggung jawab para pendidik yaitu orang tua, guru dan para tokoh masyarakat. Orang tua merupakan pendidik kodrati karena Allah sudah mengamanahi anak yang mesti dididik dengan akhlak islami. Proses pendidikan di sekolah akan terus berlangsung karena dukungan dari berbagai komponen yaitu adanya siswa, guru, materi pembelajaran, metode yang bervariasi dan sarana pra sarana yang lengkap.

Sekolah merupakan lembaga pendidikan yang akan memberikan arah bagi keberhasilan seseorang di masa yang akan datang. Keberhasilan di sini tidak hanya diharapkan bahwa out put atau alumni yang akan dihasilkan akan menjadi seorang yang cerdas secara intelektual tetapi juga diharapkan memiliki akhlak yang mulia.

Permasalahan akhlak mulia merupakan persoalan yang sangat krusial bagi generasi muda Indonesia. Bahkan Pendidikan Budaya Karakter Bangsa pun sudah diaplikasikan dalam kurikulum Nasional. Hal ini menunjukkan adanya kekhawatiran yang mendalam terhadap perilaku (akhlak) generasi muda saat sekarang ini.

Guru merupakan pendidik yang kedua setelah orang tua. Ini mengisyaratkan bahwa seorang guru hendaknyalah selalu berupaya untuk membantu perkembangan peserta didiknya dari segi jasmani dan rohani. Tugas dan tanggung jawab guru tidaklah hanya mengajar saja namun juga mendidik.

Menurut Abdullah al-Darraz dalam buku karya Ramayulis dan Samsul Nizar, pendidikan akhlak dalam pembentukan kepribadian muslim berfungsi sebagai pemberi nilai-nilai keislaman. Dengan adanya cermin dari nilai yang dimaksud dalam sikap dan perilaku seseorang maka tampillah kepribadiannya sebagai muslim. Muhammad Darraz menilai materi akhlak merupakan bagian dari nilai-nilai yang harus dipelajari dan dilaksanakan, hingga terbentuk kecendrungan sikap yang menjadi ciri kepribadian muslim (Ramayulis dan Nizar, 2009: 265).

Akhlak yang mulia mengandung konotasi pengaturan hubungan yang baik antara hamba dengan Allah, dengan sesamanya. dan dengan makhluk lainnya. 
Jika dianalisa lebih jauh akhlak dalam ajaran agama tidak dapat disamakan dengan etika karena etika lebih mengarah kepada sopan santun antar sesama, serta hanya berkaitan dengan tingkah laku lahiriah. Sedangkan akhlak mulia berdasarkan kepada konsep al-Qur'an dan Hadis (Shihab, 2007: 261).

Menurut Al-Darraz dalam Jalaluddin pembiasaan dalam akhlak mulia dilakukan melalui cara memberi materi pendidikan akhlak berupa : pensucian jiwa, kejujuran dan benar, menguasai hawa nafsu, sifat lemah lembut dan rendah hati, berhati-hati dalam mengambil keputusan, menjauhi buruk sangka, mantap dan sabar, menjadi teladan yang baik, beramal saleh dan berlomba-lomba berbuat baik, menjaga diri (iffah), ikhlas, hidup sederhana, pintar mendengar dan kemudian mengikutinya (yang baik.)

Menurut al-Mawardi dalam kitab Adab al-Dunya wa al-Diin, bahwa kemuliaan jiwa terbentuk melalui proses pendidikan dan senantiasa membiasakan berperilaku baik dan disiplin (Al-Basyri, $\mathrm{tt}$ : 262). Ungkapan ini menggambarkan bahwa pensucian jiwa akan mengarahkan kepada kemulian jiwa. Dan ini bisa dibentuk melalui proses pendidikan dan pembiasaan.

Berkaitan dengan hal ini Hamka juga mengemukakan bahwa perlunya kesehatan jiwa dan badan. Untuk menjaganya hendaklah diperhatikan lima perkara yaitu, bergaul dengan orangorang budiman, membiasakan pekerjaan berfikir, menahan syahwat dan marah, bekerja dengan teratur dan memeriksa cita-cita diri sendiri.

Permasalahan yang urgen untuk diselesaikan di Indonesia adalah persoalan akhlak mulia, bahkan menjadi perhatian orang dimana saja, baik dalam masyarakat yang telah maju, maupun dalam masyarakat yang masih terbelakang. Karena rusaknya akhlak seseorang mengganggu ketentraman orang lain. Jika dalam suatu masyarakat banyak yang rusak akhlaknya, maka akan goncanglah keadaan masyarakat itu.

Pendidikan akhlak mulia secara historis merupakan respon terhadap adanya kemerosotan akhlak pada masyarakat dengan karakter budaya kota, yaitu masyarakat yang cenderung ingin serba cepat, tergesa-gesa, pragmatis, hedonistik, materialistik, penuh persaingan yang tidak sehat, permissive, mengambil keputusan serba cepat, dan menghadapi berbagai masalah: sosial, ekonomi, politik, budaya, ilmu pengetahuan dan sebagainya. Masyarakat yang hidup dalam karakter budaya kota tersebut merupakan perhatian utama pendidikan akhlak (Abudin Nata, 2012: 211).

Banyak kasus terjadi di dunia pendidikan Indonesia yang berpangkal dari keburukan akhlak para peserta didik. Mulai dari kasus-kasus kekerasan yang terjadi di lembaga pendidikan seperti kasus STPDN, kekerasan yang terjadi pada acara OSPEK (Orientasi Pengenalan Pelajar/Mahasiswa di sekolah/kampus), sampai tawuran antar pelajar yang marak terjadi, bahkan pergaulan bebas.

Berkaitan denganhal itu, tentu amatlah penting menerapkan pendidikan akhlak bagi remaja, terutama remaja muslim yang semestinya bisa menjadi contoh teladan di tengah-tengah masyarakat. Jika ditilik lebih jauh lagi yang terjadi adalah bahwa masih adanya remaja Muslim belum menunjukkan identitas yang seharusnya, bahkan masih ada yang malas dalam melaksanakan sholat, kurang hormat pada orang tua dan guru, dan berkelahi dengan temannya.

Berdasarkan latar belakang di atas maka permasalahan penelitian yang ditetapkan penulis adalah;bagaimanakah implementasi pendidikan akhlak mulia di SMA Setia Dharma Pekanbaru? dan apakah faktor pendukung dan penghambat dalam implementasi 
pendidikan akhlak mulia di SMA Setia Dharma Pekanbaru?

Penelitian ini bertujuan untuk; mendeskripsikan dan menganalisis implementasi pendidikan akhlak Mulia di SMA Setia Dharma Pekanbaru serta mendeskripsikan dan menganalisis faktor pendukung dan penghambat implementasi pendidikan akhlak mulia di SMA Setia Dharma Pekanbaru.

Penelitian ini diharapkan memberikan kegunaan sebagai berikut: memberikan ide pemikiran dalam hal pendidikan akhlak mulia dan wacana pemikiran kepada pihak sekolah berkaitan dengan pendidikan akhlak mulia yang dapat dipraktekan demi terwujudnya generasi yang Islami serta menjadi bahan masukan bagi Dinas Pendidikan Kota Pekanbaru dan Provinsi Riau pada umumnya dalam menyusun program yang berkaitan dalam pendidikan akhlak mulia.

\section{KONSEP TEORI}

\section{Pengertian Pendidikan Akhlak Mulia}

Pendidikan akhlak mulia menurut Abuddin Nata adalah proses internalisasi nilai-nilai akhlak mulia kedalam diri peserta didik, sehingga nilai-nilai tersebut tertanam kuat dalam pola pikir (mindset), ucapan dan perbuatannya, serta interaksinya dengan Allah, manusia (dengan berbagai starata sosial, fungsi dan perannya serta lingkungan alam jagat raya (Abudin Nata, 2012: 209).

Menurut Muhammad Athiyah alAbrasyi pendidikan akhlak mulia (budi pekerti) adalah jiwa dari pendidikan Islam. Mencapai akhlak yang sempurna adalah tujuan sebenarnya dari pendidikan (Al-Abrasyi, tt: 22).

Perkataan "akhlaq" (berasal dari bahasa Arab) bentuk jamak dari kata "khulq" yang menurut bahasa diartikan: budi pekerti, perangai, tingkah laku atau tabiat (Ma'luf, 1986: 194). Kalimat tersebut mengandung segi-segi persesuaian dengan perkataan "khalqun" yang berarti kejadian, serta erat hubungannya dengan "khaaliq" yang berarti pencipta, dan "makhluuq" yang berarti yang diciptakan.

\begin{tabular}{cr}
\multicolumn{2}{c}{ Perumusan pengertian "akhlak" } \\
timbul sebagai media yang
\end{tabular} memungkinkan adanya hubungan baik antara Khalik dengan makhluk dan antara makhluk dengan makhluk (Amin, 1995: 52). Akhlak ialah kebiasaan kehendak. Ini berarti bahwa kehendak itu bila dibiasakan akan sesuatu maka kebiasaannya itu disebut akhlak. Contohnya bila kehendak itu dibiasakan memberi maka kebiasaan itu ialah akhlak dermawan (Miskawaih, 1997: 56).

Menurut Ibnu Miskawaih akhlak adalah suatu perbuatan yang lahir dengan mudah dari jiwa yang tulus, tanpa memerlukan pertimbangan dan pemikiran lagi. Jadi pada hakekatnya akhlak ialah suatu kondisi atau sifat yang telah meresap dalam jiwa dan menjadi kepribadian hingga dari situ timbullah berbagai macam perbuatan dengan cara spontan dan mudak tanpa dibuat-buat dan tanpa memerlukan pemikiran. Apabila dari kondisi tadi timbul kelakuan yang baik dan terpuji menurut pandangan syariat dan akal pikiran, maka ia dinamakan budi pekerti mulia (akhlakul mahmudah) dan sebaliknya apabila yang lahir kelakuan yang buruk, maka disebutlah budi pekerti tercela (akhlakul mazmumah). Juga disyaratkan, suatu perbuatan dapat dinilai baik jika timbulnya perbuatan itu den gan mudah sebagai suatu kebiasaan tanpa memerlukan pemikiran.

\section{Urgensi Pendidikan Akhlak bagi Remaja}

Remaja adalah masa depan orangtua, masyarakat dan bangsa. Sebab di tangan merekalah ditentukan nasib suatu bangsa. Namun akhir-akhir ini banyak terdengar keluhan orangtua, pendidik dan orangorang yang berkecimpung dalam bidang 
agama dan sosial, berkenan dengan ulah perilaku remaja yang sukar dikendalikan, nakal, keras kepala, berbuat keonaran, maksiat, tawuran, mabuk-mabukan, penyalahgunaan narkoba, bergaya hidup hippies seperti di Barat, bahkan melakukan tindakan pembajakan, pemerkosaan, pembunuhan dan tingkah laku penyimpangan dan kriminal lainnya.

Gejala kemerosotan akhlak mulia dewasa ini sudah mengkhawatirkan. Kejujursan, kebenaran dan keadilan, tolong menolong dan kasih sayang telah tertutup oleh penyelewengan, penipuan, penindasan, saling menjegal dan saling merugikan. Banyak terjadi adu domba dan fitnah, menjilat, menipu, mengambil hak orang lain sesuka hati, dan perbuatanperbuatan maksiat lainnya.

Permasalahan akhlak mulia tersebut tidak dihinggapi oleh mereka yang telah dewasa, bahkan telah menjalar sampai kepada tunas-tunas muda yang kita harapkan untuk melanjutkan perjuangan membela bangsa dan negara kita (Darajat, 1976: 9).

Tingkahlaku yang ditunjukkan oleh sebagian generasi muda harapan masa depan tersebut sungguhpun jumlahnya hanya sepersekian persen dari jumlah pelajar secara keseluruhan, sungguh amat disayangkan karena telah mencoreng kredibilitas dunia pendidikan. Para pelajar yang seharusnya menunjukkan akhlak yang baik sebagai hasil didikan itu, justru malah menunjukkan tingkah laku yang buruk.

Tidak diragukan lagi, bahwa akhlak, sikap dan perilaku merupakan salah satu buah dari iman yang kuat dan pertumbuhan sikap keberagamaan seseorang yang benar. Jika sejak masa kanak-kanaknya, ia tumbuh dan berkembang dengan berpijak pada landasan iman kepada Allah SWT dan terdidik untuk selalu takut, ingat, pasrah, dan meminta pertolongan dan berserah diri kepada-Nya, maka ia akan memiliki kemampuan dan bekal pengetahuan di dalam menerima setiap keutamaan dan kemuliaan, disamping terbiasa dengan sikap akhlak mulia. Sebab benteng pertahanan religius yang berakar pada hati sanubarinya, kebiasaan mengingat Allah yang telah dihayati dalam dirinya dan intropeksi diri yang telah menguasai seluruh pikiran dan perasaan, telah memisahkan anak dari sifat-sifat jelek, kebiasaan-kebiasaan bermaksiat, dan tradisi-tradisi jahiliyah yang rusak. Bahkan setiap kebaikan akan diterima menjadi salah satu kebiasaan, kesenangan dan kemuliaan akan menjadi akhlak dan sifat yang paling utama (Nasih Ulwan, 2011: 133).

Beberapa perilaku menyimpang dikalangan remaja antara lain;kenakalan ringan, misalnya keras kepala, tidak mau patuh kepada orangtua dan guru, bolos dari sekolah, tidak mau belajar, sering berkelahi, suka mengeluarkan kata-kata kurang sopan, kotor, cara berpakaian dan lagak lagu yang tidak peduli, dan sebagainya, kenakalan yang mengganggu ketentraman dan keamanan orang lain. Misalnya mencuri, memfitnah, merampok, menodong, menganiaya, merusak milik orang lain, kebut-kebutan, membunuh dan sebagainya, kenakalan seksual misalnya pergaulan sex bebas, homoseksual dan lesbian (Darajat, 1976: 10).

Faktor-faktor yang menyebabkan timbulnya perilaku menyimpang di kalangan para remaja antara lain ; kurang tertanamnya jiwa agama pada tiap-tiap individu dalam masyarakat, keadaan masyarakat yang kurang stabil, baik dari segi ekonomi, sosial maupun politik, pendidikan akhlak mulia tidak terlaksana menurut mestinya, baik di rumah tangga, sekolah, maupun masyarakat, suasana rumah tangga yang kurang baik, diperkenalkannya secara populer obatobatan dan alat kontrasepsi, banyaknya tulisan-tulisan, gambar-gambar, siaran, kesenian-kesenian yang tidak mengindahkan dasar-dasar tuntunan moral, kurang adanya bimbingan untuk 
mengisi waktu luang dengan kegiatan yang baik dan membawa kepada pembinaan akhlak mulia, tidak ada atau kurangnya pusat-pusat bimbingan dan penyuluhan bagi anak-anak dan pemuda.

Hal ini membuktikan bahwa kedudukan akhlak dalam kehidupan manusia menempati tempat yang penting sekali, baik sebagai individu maupun sebagai anggota masyarakat dan bangsa. Sebab jatuh bangunnya, jaya hancurnya suatu bangsa dan masyarakat tergantung kepada bagaimana akhlaknya (Djatnika, 1996: 11). Oleh karena itu para pendidik hendaknya mulai memperhatikan pendidikan akhlak karena tanggung jawab pendidikan akhlak adalah tanggung jawab bersama.

Keluarga merupakan tempat pendidikan awal bagi seorang anak, sebelum ia masuk ke sekolah formal. Jika berbicara tentang pendidikan akhlak maka mesti dibiasakan dari kecil sehingga ketika ia sudah remaja yang akan mewarnai sikap dan tingkah lakunya sehari-hari adalah akhlak mahmudah (terpuji).

\section{Metode Pendidikan Akhlak Mulia}

Abdullah Nashih Ulwan mengungkapkan bahwa pendidikan akhlak adalah serangkaian prinsip dasar moral dan keutamaan sikap serta watak (tabiat) yang harus dimiliki dan dijadikan kebiasaan oleh anak sejak masa pemula hingga ia menjadi mukallaf, yakni siap mengarungi lautan kehidupan. Tidak diragukan lagi, bahwa moral, sikap, dan tabiat merupakan salah satu buah iman yang kuat dan pertumbuhan sikap keberagamaan seseorang yang benar.

Jika sejak masa kanak-kanaknya, ia tumbuh dan berkembang dengan berpijak pada landasan iman kepada Allah dan terdidik untuk selalu takut, ingat, pasrah dan meminta pertolongan dan berserah diri kepada Allah, ia kan memiliki kemampuan dan bekal pengetahuan di dalam menerima setiap keutamaan dan kemuliaan,disamping terbiasa dengan sikap akhlak mulia. Sebab benteng pertahanan religius yang berakar pada hati sanubarinya, kebiasaan mengingat Allah yang telah dihayati dalam dirinya dan instropeksi diri yang telah menguasai seluruh pikiran dan perasaan, telah memisahkan anak dari sifat-sifat jelek, kebiasaan-kebiasaan dosa, dan tradisitradisi jahiliyah yang rusak. Bahkan setiap kebaikan akan diterima menjadi salah satu kebiasaan dan kesenangan, dan kemuliaan akan menjadi akhlak dan sifat yang paling utama (Djatnika, 1996: 193).

Untuk memperoleh hasil yang baik dalam pelaksanaan pendidikan akhlak maka harus memenuhi beberapa faktorfaktornya. Salah satu faktornya adalah metode. Metode merupakan sarana untuk menyampaikan isi atau materi pendidikan tersebut, agar tujuan yang diharapkan dapat tercapai dengan hasil yang baik.

Diantara metode pendidikan akhlak mulia yang ditawarkan oleh Abdullah Nashih Ulwan adalah; (Ulwan, 2011: 141) pendidikan dengan keteladanan, pendidikan dengan adat kebiasaan, pendidikan dengan pembiasaan, pendidikan dengan nasihat, pendidikan dengan perhatian dan pendidikan dengan memberikan hukuman.

Menurut al-Ghazali anak adalah amanat bagi orang tuanya. Hatinya yang suci merupakan permata tak ternilai harganya, masih murni dan belum terbentuk (Mubarok Al-Barik, 1998: 247).

Orang tuanya merupakan arsitek atau pengukir kepribadian anaknya. Sebelum mendidik orang lain, sebaiknya orang tua harus mendidik pada dirinya terlebih dahulu. sebab anak merupakan peniru ulung. Begitu juga guru sebagai pendidik, segala informasi yang masuk pada diri anak, baik melalui penglihatan dan pendengaran dari orang di sekitarnya, termasuk guru akan membentuk karakter anak tersebut. Bahkan sampai usia remaja pun memerlukan pendidikan dari orang tua dan gurunya ('Isawi, 1994: 35). 
Teladan yang baik dari pendidik akan berpengaruh besar kepada perkembangan remaja di masa mendatang. Sebab kebaikan di waktu remaaja menjadi dasar untuk pengembangan di masa dewasa kelak. Untuk itu pendidik sebanyak mungkin memberikan keteladanan bagi para remaja . Dengan keteladanan akan memudahkan remaja untuk menirunya. Sebab keteladanan lebih cepat mempengaruhi tingkah laku remaja. Apa yang dilihatnya akan ia tirukan dan lama kelamaan akan menjadi tradisi bagi remaja. Hal ini sesuai firman Allah SWT Q. S. al-Ahzab/ $33: 21$.

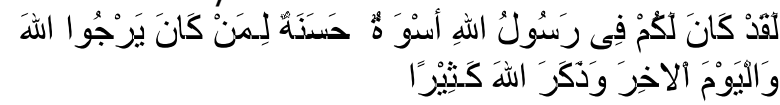

Artinya: "Sesungguhnya telah ada pada (diri) Rasulullah itu suri teladan yang baik bagimu (yaitu) bagi orang yang mengharap (rahmat) Allah dan (kedatangan) hari kiamat dan dia banyak menyebut Allah." (DEPAG, 2002: 595).

Dalam hal keteladanan ini, lebih jauh Abdullah Nashih Ulwan menafsirkan dalam beberapa bentuk, yaitu; (Ulwan, 2011: 470-479) keteladanan dalam ibadah, keteladanan bermurah hati., keteladanan kerendahan hati, keteladanan kesantunan, keteladanan keberaniann dan keteladanan memegang akidah

Karena obyeknya remaja tentunya bagi pendidik dalam memberikan teladan harus sesuai dengan perkembangannya sehingga remaja mudah mencerna apa yang disampaikan oleh para pendidik. Sebagai contoh remaja dibiasakan, mengucapkan salam terlebih dahulu kepada para sahabatnya sebagai implementasi dari sifat rendah hati, maka senantiasa para pendidik harus memberikan ajaran tersebut setiap hari yaitu hendak pergi dan pulang ke rumah (keteladanan kerendahan hati). Yang penting para pendidik tampil dihadapan para remaja sesuai dengan ajaran-ajaran Islam, niscaya semua itu akan ditirunya.
Setiap manusia yang dilahirkan membawa potensi, salah satunya berupa potensi beragama. Potensi beragama ini dapat terbentuk pada diri remaja (manusia) melalui 2 faktor, yaitu : faktor pendidikan Islam yang utama dan faktor pendidikan lingkungan yang baik. Faktor pendidikan Islam yang bertanggung jawab penuh adalah para pendidik. Ia merupakan pembentuk karakter anak. Sedangkan pendidik di rumah adalah orang tua, hal ini sesuai dengan sabda Rasul SAW yang diriwayatkan oleh Muslim dan Abu Hurairah (Imam Muslim, tt: 2047).

عن ابى هريزة رضي الله عذه قال: قال رسول الله صلى إلى إلى

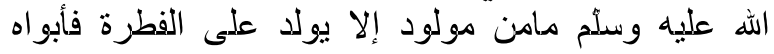

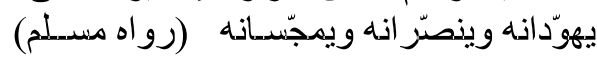
Artinya : "Dari Abi hurairah ra. telah bersabda Rasulullah SAW. tidak ada anak yang dilahirkan, kecuali dalam keadaan fitrah. Maka kedua orang tuanyalah yang akan menjadikannya sebagai orang yahudi, nasrani, atau majusi". (HR. Muslim)

Setelah remaja diberikan masalah pengajaran agama sebagai sarana teoritis dari para pendidik, maka faktor lingkungan harus menunjang terhadap pengajaran tersebut, yakni para pendidik senantiasa memberikan aplikasi pembiasaan ajaran agama dalam lingkungan keluarga dan sekolah. Sebab pembiasaan merupakan upaya praktis dan pembentukan (pembinaan) dan persiapan (Ulwan, 2011: 141).

Pada remaja, teman mempunyai pengaruh yang besar, sebagaimana hadis Nabi : "Seseorang berada dalam tuntunan temannya, maka hendaklah salah seorang dari kamu melihat siapa yang menjadi temannya".

Dari hadis ini dapat memberikan pemahaman, bahwa teman mempunyai pengaruh yang besar terhadap seseorang. Jika si teman baik dan bertakwa maka sesorang dapat mengambil sifat baik dan takwanya. Dan inilah yang dimaksud dengan faktor lingkungan sosial, baik di 
ssekolah maupun di tempat- tempat lainnya.

Remaja yang menerima pendidikan yang baik dari orang tuanya yang saleh dan pengajarnya (guru) yang tulus, disamping tersedianya lingkungan yang baik dan teman yang saleh, mukmin dan tulus, maka tidak diragukan lagi bahwa remaja tersebut akan terdidik dalam keutamaan iman dan takwa. Ia juga akan terbiasa dengan akhlak luhur, etika yang mulia, dan kebiasaan yang terpuji.

Hal ini sesuai dengan sabda Rasul SAW yang diriwayatkan al-Tirmidzi dari Ayyub bin Musa (Sunan At-Tarmizi, tt: 298).

حدثنا ايوب ابن موسى عن ابى عن جده أنّ رسول اله اله

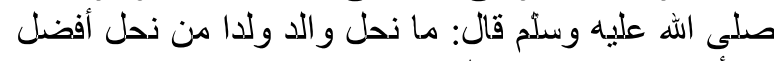

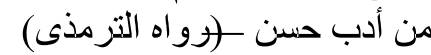

Artinya : "Diceritakan dari Ayyub bin Musa dari ayahnya dari kakeknya, bahwa Rasulullah saw bersabda : Tidak ada pemberian yang lebih utama dari seorang ayah kepada anaknya kecuali budi pekerti yang baik". (H.R At-Tirmidzi)

Apabila seorang remaja dalam keluarganya memperoleh bimbingan, arahan, dan adanya saling menyayangi antar anggota keluarga, niscaya lambat laun remaja akan terpengaruh informasi yang ia lihat dan ia dengar dari semua perilaku orang- orang disekitarnya. Dan pengawasan dari orang tua dan pendidik sangat diperlukan sebagai kontrol atas kekeliruan dari perilaku remaja yang tak sesuai dengan ajaran Islam.

Berkaitan dengan pendidikan dengan nasihat maka pemberi nasihat seharusnya orang yang berwibawa di mata para remaja. Dan pemberi nasihat di sekolah tentunya guru sebagai pendidik bagi remaja. Remaja akan mendengarkan nasihat tersebut, apabila pemberi nasihat juga bisa memberi keteladanan. Sebab nasihat saja tidak cukup bila tidak diikuti dengan keteladanan yang baik.

Remaja tidak akan melaksanakan nasihat tersebut apabila didapatinya pemberi nasihat tersebut juga tidak melaksanakannya. Remaja tidak butuh segi teoritis saja, tapi segi praktislah yang akan mampu memberikan pengaruh bagi diri remaja. Nasihat yang berpengaruh, membuka jalannya ke dalam jiwa secara langsung melalui perasaan. Setiap manusia (remaja) selalu membutuhkan nasihat, sebab dalam jiwa terdapat pembawaan itu biasanya tidak tetap, dan oleh karena itu kata-kata atau nasihat harus diulang-ulang (Salman Harun, 1993: 334). Nasihat akan berhasil atau mempengaruhi jiwa remaja, tatkala pendidik mampu memberikan keadaan yang baik. Hal ini sesuai dengan firman Allah SWT dalam QS. al-Baqarah (2) : 44.

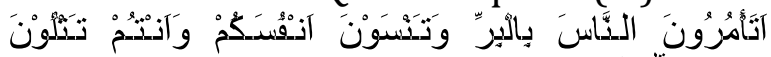

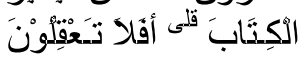
Artinya : "Mengapa kamu suruh orang lain (mengerjakan) kabaktian, sedang kamu melupakan diri (kewajiban) mu sendiri, Padahal kamu membaca al-Kitab (Taurat) ? maka tidakkah kamu berpikir? (DEPAG, 2002: 8).

Agar harapan pendidik terpenuhi yakni remaja mengikuti apa-apa yang telah diperintahkan dan yang telah diajarkannya, tentunya disamping memberikan nasihat yang baik juga ditunjang dengan teladan yang baik pula. Karena pembawaan remaja mudah terpengaruh oleh kata-kata yang didengarnya dan juga tingkah laku yang sering dilihatnya dalam kehidupan seharihari dari pagi hari sampai sore hari.

Nasihat juga harus diberikan sesering mungkin kepada para remaja, masa Sekolah Menengah Kejuruan, sebab remaja sudah bersosialisasi dengan teman sebayanya. Agar apa-apa yang telah diberikan dalam pendidikan sekolah tidak mudah luntur atau tepengaruh dengan lingkungan barunya.

Menurut Ulwan, dalam penyajian atau memberikan nasihat itu ada pembagiannya, yaitu; (Ulwan, 2011: 209287) menyeru untuk memberikan kepuasan dengan kelembutan atau penolakan. Sebagai contohnya adalah seruan Lukman kepada anak-anaknya, 
agar tidak mempersekutukan Allah SWT. Q.S. Lukman (31) :13.

وأذ قال لقمن لابـنه وهو يعظه يـبنـي لاتشرك باله قلى إن الشرك لظلم عظيم

Artinya : "Dan (ingatlah) ketika Luqman berkata kepada anaknya, di waktu ia memberi pelajaran kepadanya : "Hai anakku, janganlah kamu mempersekutukan Allah, Sesungguhnya mempersekutukan (Allah) adalah benarbenar kezaliman yang besar." (DEPAG, 2002: 581).

Metode kisah (cerita) dengan disertai tamsil ibarat dan nasihat juga mempunyai pengaruh terhadap jiwa dan akal. Biasanya remaja itu menyenangi tentangkisah-kisah yang mengandung hikmah. Untuk itu para pendidik sebisa mungkin untuk memberikan masalah kisah yang berkaitan dengan keteladanan yang baik yang dapat menyentuh perasaannya.Sebagaimana firman-Nya dalam QS. al-A`raf (7) : 176.

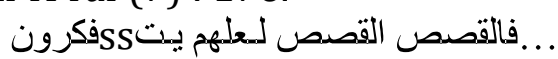

Artinya: “... Maka ceritakanlah (kepada mereka) kisah-kisah itu agar mereka berpikir". (DEPAG, 2002: 233).

Al-Qur'an sangat dipenuhi oleh ayatayat yang disertai wasiat dan nasehat, nash-nash yang mengandung arahan kepada pembaca terhadap apa yang mendatangkan manfaat dalam agama, dunia dan akhiratnya. Juga yang bermanfaat bagi dirinya secara spritual, mental dan fisikal. Diantara arahan AlQur'an tersebut sebagaimana termaktub dalam QS. Luqman : 13 dan QS. Al-Furqan ayat 62-77.

Pendidik yang bertanggung jawab tentunya akan berusaha menjaga amanatNya dengan memberikan yang terbaik buat peserta didiknya demi masa depannya dan demi keselamatannya. Sebagai pendidik berkewajiban untuk memperhatikan kebutuhan-kebutuhan peserta didiknya, baik kebutuhan jasmani ataupun kebutuhan yang berbentuk rohani. Diantara kebutuhan peserta didik yang bersifat rohani adalah ingin diperhatikan dalam perkembangan dan pertumbuhannya.

Pendidikan dengan perhatian adalah mencurahkan, memperhatikan dan senantiasa mengikuti perkembangan peserta didik dalam pembinaan akidah dan moral, persiapan spiritual dan sosial, disamping selalu bertanya tentang situasi pendidikan jasmani dan daya hasil ilmiahnya. Pendidik yang bijaksana tentunya mengetahui perkembanganperkembangan peserta didiknya.

Pendidik senantiasa akan mengoreksi perilaku peserta didiknya yang tidak baik dengan perasaan kasih sayangnya, sesuai dengan perkembangan usianya. Sebab pengasuhan yang baik akan menanamkan rasa optimisme, kepercayaan, dan harapan peserta didik dalam hidupnya. Dalam memberi perhatian ini, hendaknya peserta didik bersikap selayak mungkin, tidak terlalu berlebihan dan juga tidak terlalu kurang. Namun perhatian pendidik disesuaikan dengan perkembangan dan pertumbuhan peserta didik.

Apabila pendidik mampu bersikap penuh kasih sayang dengan memberikan perhatian yang cukup, niscaya peserta didik akan menerima pendidikan tersebut dengan penuh perhatian juga. Namun pangkal dari seluruh perhatian yang utama adalah perhatian dalam akidah.

Berkaitan dengan pendidikan dengan memberikan hukuman dapat dipahami bahwa hukuman diberikan, apabila metode-metode yang lain sudah tidak dapat merubah tingkah laku peserta didik, atau dengan kata lain cara hukuman merupakan jalan terakhir yang ditempuh oleh pendidik, apabila ada perilaku peserta didik yang tidak sesuai dengan ajaran Islam. Sebab hukuman merupakan tindakan tegas untuk mengembalikan persoalan di tempat yang benar. Hukuman sesungguhnya tidaklah mutlak diberikan. Karena ada orang dengan teladan dan nasehat saja sudah cukup, tidak memerlukan hukuman. Tetapi pribadi 
manusia tidak sama seluruhnya. Sebenarnya tidak ada pendidik yang tidak sayang kepada siswanya.. Dengan memberikan hukuman, pendidik sebenarnya merasa kasihan terhadap peserta didiknya yang tidak mau melaksanakan ajaran Islam. Karena salah satu fungsi dari hukuman adalah mendidik. Sebelum peserta didik mengerti peraturan, ia dapat belajar bahwa tindakan tertentu benar apabila tidak menerima hukuman dan tindakan lainnya salah apabila mendapatkan suatu hukuman.

Dalam memberikan hukuman ini diharapkan pendidik memperhatikan ruang waktu dan tempatnya. Diantara metode memberikan hukuman kepada anak adalah; menghukum peserta didik dengan lemah lembut dan kasih sayang, menjaga tabiat peserta didik yang salah dalam menggunakan hukuman, hukuman diberikan sebagai upaya perbaikan terhadap diri peserta didik, dengan tahapan yang paling akhir dari metodemetode yang lain.

Memberi hukuman pada peserta didik, seharusnya para pendidik sebisa mungkin menahan emosi untuk tidak memberi hukuman berbentuk badaniah. Kalau hukuman yang berbentuk psikologis sudah mampu merubah sikap peserta didik, tentunya tidak dibutuhkan lagi hukuman yang menyakitkan anak tersebut. Menurut Nashih Ulwan, hukuman bentuknya ada dua, yakni hukuman psikologis dan hukuman biologis.

Bentuk hukuman yang bersifat psikologis adalah; menunjukkan kesalahan dengan pengarahan, menunjukkan kesalahan dengan memberikan isyarat, menunjukkan kesalahan dengan kecaman.Hukuman bentuk psikologis ini diberikan kepada anak dibawah umur 10 tahun. Apabila hukuman psikologis tidak mampu merubah perilaku anak, maka hukuman biologislah yang dijatuhkan tatkala anak sampai umur 10 tahun tidak ada perubahan pada sikapnya. Hal ini dilakukan supaya anak jera dan tidak meneruskan perilakunya yang buruk. Sesuai sabda Rasul SAW yang diriwayatkan Abu Daud dari Mukmal bin Hisyam (Abi Daud, tt: 133).

حدثنا مأمل بن هثام قال: قال رسول اله صلى اله عليه

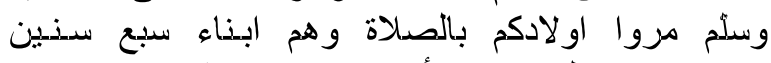

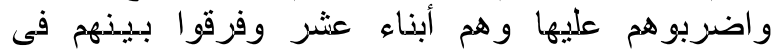
المضاجع - -روواه (بو داود)

Artinya: "Suruhlah anak kalian mengerjakan shalat, sedang mereka berumur tujuh tahun, dan pukulilah mereka itu karena shalat ini, sedang mereka berumut sepuluh tahun, dan pisahkanlah tempat tidu mereka". (HR. Abu Daud).

Jadi dapat dipahami bahwa pendidikan dengan memberikan hukuman ini dapat di lakukan setelah melewati berbagai tahapan yaitu pendidikan dengan keteladanan, pendidikan dengan adat istiadat, pendidikan dengan pembiasaan, pendidikan dengan nasihat dan pendidikan dengan perhatian. Apabila tahapan ini sudah dilakukan dengan proses yang baik dan akhlak mulia telah terimplementasi dengan baik, tentunya pendidikan dengan memberikan hukuman ini ttidak akan perlu untuk dilaksanakan.

Berdasarkan temuan empirik ada beberapa penelitian yang hampir memiliki kemiripan dengan kajian penelitian ini antara lain: pertama, penelitian yang dilakukan oleh Dr. Ajat Sudrajat, dkk (Dosen UNY) dengan judul Model Pembentukan Kultur Akhlak Mulia Siswa SMP di Indonesia. Penelitian ini dilaksanakan di sekolah-sekolah di Pulau Jawa, dengan mengambil sampel sekolahsekolah di DKI Jakarta, Jawa Barat, Yogyakarta, dan Jawa Timur. Hasil penelitian menunjukkan bahwa ada variasi model pembentukan kultur akhlak mulia bagi siswa di sekolah-sekolah di Indonesia. Dari delapan sekolah yang menjadi sampel penelitian ini terlihat jelas variasi tersebut. Namun demikian jika 
dicermati ternyata ada kesamaan umum dari semua sekolah sampel yang diteliti, yakni menjadikan visi, misi, atau tujuan sekolah sebagai dasar pijakan untuk membangun kultur akhlak mulia di sekolah. Terwujudnya visi, misi, dan tujuan sekolah ini perlu didukung dengan program-program sekolah yang tegas dan rinci yang mengarah pada terwujudnya kultur akhlak mulia di sekolah. Programprogram ini akan berjalan dengan baik jika mendapatkan dukungan yang positif dari semua pihak yang terkait. Model ideal yang sebaiknya dikembangkan dalam pembentukan kultur akhlak mulia di sekolah di Indonesia baik di sekolah dasar maupun menengah adalah: sekolah sebaiknya merumuskan visi, misi, dan tujuan sekolah yang mengarah pada pembentukan kultur akhlak mulia di sekolah, ada dukungan berupa persepsi yang sama di antara civitas sekolah, ada kesadaran yang tinggi bagi seluruh civitas sekolah, ada kebijakan yang tegas dari kepala sekolah, ada program-program dan tata tertib sekolah yang jelas dan tegas, ada pembiasaan nilai-nilai akhlak mulia dalam aktivitas sehari-hari di sekolah baik yang bersifat keagamaan maupun yang umum, ada dukungan dari semua pihak yang terkait dalam mewujudkan kultur akhlak mulia di sekolah, ada keteladanan dari para guru dan karyawan, ada sinergi antara tiga pusat pendidikan, ada reward dan punishment, dibutuhkan waktu yang lama dan dilakukan secara berkelanjutan, serta melibatkan semua mata pelajaran yang diajarkan di sekolah.

Kedua, penelitian yang dilakukan oleh Nur Dewi Afifah dengan judul Pengembangan Model Pembelajaran Untuk Meningkatkan Akhlak Mulia Peserta Didik Pada Mata Pelajaran PAI Madrasah Diniyah Awwaliyah (MDA). Hasilnya adalah (1) Pertama, intervensi proses pembelajaran berupa rekayasa model pembelajaran merupakan kebutuhan. Hal itu didasarkan pada kelemahan proses pembelajaran, rendahnya kreativitas guru, dan sarana yang tidak mendukung tumbuh kembangnya akhlak mulia peserta didik; (2) model yang dikembangkan adalah model yang valid berdasarkan uji validitas internal dan eksternal (uji luas). Kontennya bersifat integratif, diorganisasikan secara tematis, dan diimplementasikan dalam pembelajaran dengan prinsip plan-doevaluate; dan (3) model yang dikembangkan efektif meningkatkan pemahaman dan akhlak mulia peserta didik secara signifikan dengan derajat peningkatan sangat baik. Model pembelajaran memiliki implikasi teoretis maupun praktis bagi studi pengembangan kurikulum, yaitu: (a) pembelajaran PAI tidak sekedar mentransfer pengetahuan dan nilai kepada peserta didik, tetapi yang paling penting adalah penguatan akhlak peserta didik; (b) pembelajaran PAI akan efektif jika nilai-nilai ajaran Islam sebagai spirit yang mendasari proses pembelajaran mampu dipadukan dengan penguatan akhlak mulia secara kontekstual; (c) pembelajaran PAI akan efektif jika ada keteladanan yang diberikan guru dalam proses pembelajaran, dan mewariskan nilai-nilai positif melalui keterlibatan aktif peserta didik dalam keseluruhan kegiatan pembelajaran; (d) pembelajaran PAI dengan langkah-langkah: orientasi, aktualisasi, presentasi, verifikasi, dan refleksi, efektif meningkatkan ahklak mulia peserta didik. Direkomendasikan agar kepala madrasah dan guru hendaknya mempertimbangkan penggunaan model ini untuk meningkatkan akhlak dan mengaktifkan peserta didik dalam belajar, demikian pula peneliti lain hendaknya melanjutkan penelitian ini dengan mata pelajaran dan pada jenjang dan kelas yang berbeda, serta cakupan yang lebih luas dengan sampel yang lebih besar. LPTK terutama di PTAI dapat memanfaatkan sebagai model pilihan dalan penguatan akhlak peserta didik. 
Ketiga, penelitian yang dilakukan oleh Ani Nuryani dengan judul Kajian Pembinaan Akhlak Mulia Melalui Kegiatan EkstraKurikuler Rohani Islam (Rohis) di Sekolah : Studi Kasus di SMA Negeri 1 Lembang Bandung Barat. Hasil penelitian menunjukan bahwa kegiatan ekstrakurikuler ROHIS di SMA Negeri 1 Lembang berdampak positif terhadap perkembangan aakhlak mulia anggotanya, seperti taat beribadah, menutup aurat, disiplin, toleransi, kejujuran, dan menghormati sesama, keberanian, dan berani berkata benar. Hal yang dapat direkomendasikan adalah:

Kementerian Agama sebagai lembaga yang membidangi pendidikan agama di sekolah hendaknya membuat pedoman yang jelas dan melakukan pendampingan terhadap pelaksanaan kegiatan ekstrakurikuler keagamaan. (2) Program Studi Pendidikan Umum harus mempertegas pengembangan pembinaan etika, moral dan akhlak yang tercermin dalam kurikulum dan interaksi pembelajarannya, khususnya dalam pembinaan akhlakul karimah. (3) Sekolah dalam hal ini Kepala Sekolah hendaknya membuat kebijakan untuk menjadikan ekstrakurikuler Rohis sebagai ekstrakurikuler yang wajib diikuti oleh seluruh siswa sehingga perubahan akhlak mulia siswa lebih terlihat. (4) Bagi sekolah yang mayoritas siswanya beragama Islam, kegiatan ekstrakurikuler Rohis harus lebih diutamakan dalam pembinaan akhlakul karimah siswa.

\section{HASIL PENELITIAN}

\section{Sejarah SMA Setia Dharma}

Sejarah SMA Setia Dharma di awali sekitar tahun 1952, alumni/ pelajar SMP yang berada di Peknbaru dan daerah Riau lainnya mendesak Bupati Kampar yang berlokasi di Pekanbaru untuk mendirikan sebuah SMA. Memenuhi harapan pemudapemuda ini, maka Bupati Kampar Bapak Dt. Wan abdul Rachman membentuk sebuah panitia pembentuk SMA yang anggotanya terdiri dari staf beliau yang di ketuai oleh Abdul Muin Dt. Rangkayo Maharjo dan sekretaris yaitu Muhammad Yubhaar.

Kemudian panitia ini ditambah dengan karyawan Departemen Pendidikan dan Kebudayaan, bapak Suman Hasibuan. Panitia ini mendirikan gedung resmi permanen yang berlokasi di Jalan Prof. M. Yamin, SH Pekanbaru. Pada awalnya sekolah ini bernama SMA Pekanbaru. Pada awal tahun (1952-1953) SMA ini mulai menerima murid baru, belajar siang/sore hari karena muridmuridnya banyak yang bekerja sebagai pegawai negeri/swasta, polisi, TNI, dan sebagainya. Jadi SMA Setia dharma ini adalah Sekolah Menengah Atas (SMA) pertama di Riau.

Dalam rapat pembentukan yayasan pada tanggal 8 Nopember 1963 bertempat di Kantor Walikota Jalan Ahmad Yani Pekanbaru yang dipimpin oleh Dt. Wan Abdul Rachman telah diambil keputusan membentuk yayasan, yang bernama Yayasan Pendidkan Setia Dharma. Yayasan ini dikukuhkan dengan akta notaris Swawal Sutan di atas Nomor 7 taanggal 13 januari 1964. Anggota yayasan ini terdiri dari unsur panitia pembentuk SMA Setia Dharma Pekanbaru, pemerintah daerah, tokoh masyarakat, pengusaha dan kepala sekolah SMA Setia Dharma Pekanbaru.

Yayasan ini terdiri dari dua badan, yakni dewan pengurus dan dewan penasehat. Struktur dan personalia dewan pengurus yang pertama kalinya diangkat, tercantum dalam akte Notaris ini ini diketuai oleh Bapak Dt. Wan Abdul Rachman. Susunan dewan pengurus ini adaalah sebagai berikut:

Ketua umum : Dt. Wan Abdul Rachman (Wakil Gubernur Riau).

Ketua I : Tengku Bay (Walikota Pekanbaru).

Ketua II : Suman Hasibuan (Pegawai PNS Depdikbud).

Sekretaris I: M. Yubhaar (Sekda Riau). 
Sekretaris II: Raja Rusli, BA (SEKO Pekanbaru).

Bendahara: Ahmad Abbas (Pengusaha Besar)

Wakil Bendaraha: Johanis Junid ( KEP. SMA Setia Dharma).

Pembantu-Pembantu: Abdul Muin Dt. Rangko (Tokoh Masyarakat), M. Husin (Peg. Perdagangan provinsi Riau), Idrus (Peg. Bupati Kampar), Rusli Danur, BA (Peg. Bupati Kampar), Tengku Muhammad Anzam (Tokoh Masyarakat).

Personil pengurus di atas tidak pernah diubah (menurut hukum) sampai tahun 2006. Dewan pengurus ini mengangkat dewan pelindung/penasihat sebagai berikut: Gubernur Daerah Tingkat I Riau, Walikotamadya Kepala Daerah Tngkat II Pekanbaru, Kepala Kantor Wilayah Departemen Pendidikan dan Kebudayaan Provinsi Riau, Pengurus harian disusun oleh dewan pengurus mengacu pada pasal 9 anggaran Dasar/Akta notaris, susunan pengurus ini adalah sebagai berikut:

Ketua : H. Suman Hasibuan.

Sekretaris : H. M. Yubhaar.

Bendahara : Johanis Junid.

Pembantu : Idrus.

Kepala SMA Setia Dharma Pekanbaru berturut-turut adalah: Akmal Yunus, Johanis Junid, Rumzi Rusli, Jusnir, Drs. Verri, Drs. H. Bachtiar (sampai sekarang).

Adapun data Identitas sekolah SMA Setia Dharma Pekanbaru dapat di uraikan sebagai berikut:

Nama Sekolah

Dharma Pekanbaru

NIS/NSS

304096002006

Tahun berdiri Sekolah $\quad$ : 1952

Surat keputusan/SK : Menkumham

No. AHU, 4092-AH-01/02 Tahun 2008

Status Sekolah

Alamat

Yamin, SH, No. 67

Desa

Kecamatan

: Swasta

Kabupaten/kota
Provinsi

: Riau

Relepon

21282

Kurikulum

KTSP

Penyelenggara

Luas tanah

Luas bangunan

Tahun berdiri

\section{Visi dan Misi SMA Setia Dharma Pekanbaru}

Visi SMA Setia Dharma adalah terwujudnya SMA Setia Dharma berkualitas, berprestasi, mampu bersaing yang dilandasi nilai-nilai budaya dan karakter bangsa.

Misi SMA Setia Dharma Pekanbaru ; mewujudkan sekolah berstandar Nasional, mengembangkan potensi peserta didik melalui berbagai model pembelajar menuju insan terpuji, meningkatkan perolehan nilai UN dan US, melaksanakan kegiatan pengembangan diri semua minat dan bakat siswa, membuat semangat keunggulan secara intensif dan daya asing yang sehat kepada seluruh warga sekolah baik prestasi akademik maupun non akademik, melaksanakan kegiatan siswa yang menumbuhkembangkan nilai-nilai karakter bangsa dan jiwa kewirausahaan.

\section{Struktur Organisasi SMA Setia Dharma Pekanbaru}

Sekolah merupakan organisasi formal yang bergerak dalam bidang pendidikan yang pengelolaannya dipimpin oleh kepala sekolah. Untuk berjalannya sistem organisasi dan agar terciptanya suasana sekolah yang tertib dan teratur sebagaimana yang sudah dietapkan Dinas Pendidikan, maka SMA Setia dharma Pekanbaru juga mempunyai struktur organisasi. Adapun struktur organisasi SMA Setia Dharma Pekanbaru yaitu: Kepala Sekolah ; Drs. H. Bakhtiar. Waka Kurikulum; Sumarianto, S.Pd. Waka sarana Pra sarana. Dra Zuwirma, Waka 
Kesiswaan; Drs. Khairil. Kepala Tata Usaha ; Suwito.

Pendidikan memiliki peran sentral bagi upaya pembangunan sumber daya manusia. Adanya peran yang dimiliki, isi, dan proses pendidikan perlu dimutakhirkan sesuai dengan kemajuan ilmu dan kebutuhan masyarakat, implikasinya jika ada pada saat ini masyarakat Indonesia dan dunia menghenadaki sumber daya manusia yang memiliki seperangkat kompetensi yang berstandar nasional dan internasional, maka isi proses pendidikannya perlu diarahkan pada pencapaian kompetensi tersebut.

Untuk dapat terarahnya proses belajar mengajar di lembaga pendidikan maka sangat dibutuhkan suatu kurikulum yang jelas agar tujuan pembelajaran tersebut dapat tercapai sesuai dengan cita-cita pendidikan nasional.

Kurikulum yang diterapkan pada SMA Setia Dharma adalah Kurikulum 2013 berdasarkan instruksi dan pengawasan Dinas Pendidikan. Tahun Pelajaran 2015/2016 SMA ini menggunakan Kurikulum KTSP.

Untuk itu, sesuai Peraturan Pemerintah No. 19 Tahun 2005 tentang Standar Nasional Pendidikan pasal 6 ayat (1) yang menyatakan bahwa kurikulum untuk jenis pendidikan umum terdiri atas.k elompok mata pelajaran agama dan akhlak mulia. kelompok mata pelajaran kewarganegaraan dan kepribadian, kelompok mata pelajaran ilmu pengetahuan dan teknologi, kelompok mata pelajaran estetika, kelompok mata pelajaran jasmani, olahraga dan kesehatan.

Masing-masing kelompok mata pelajaran tersebut diimplementasikan dalam kegiatan pembelajaran pada setiap mata pelajaran secara menyeluruh. Dengan demikian, cakupan dari masingmasing kelompok itu dapat diwujudkan melalui mata pelajaran yang relevan. Kurikulum Kelas XII Program IPA dan
Program IPS, terdiri atas: 13 mata pelajaran,muatan lokal (konservasi dan pemberdayaan potensi bahari budaya melayu), program pengembangan diri. Alokasi waktu satu jam pembelajaran adalah 45 menit.

Kriteria Ketuntasan minimal ditentukan oleh masing-masing Guru Mata Pelajaran dengan berpedoman kepada nilai input atau rata-rata nilai terakhir yang diperoleh peserta didik pada setiap jenjang kelas. Setiap guru mata pelajaran di SMA Setia Dharma Pekanbaru meningkatkan kriteria ketuntasan minimal secara terus menerus untuk mencapai kriteria ketuntasan ideal. Ketuntasan minimal di SMA Setia Dharma Pekanbaru diserahkan kepada guru mata pelajaran dan dilaporkan kepada pihak yang terkait.

Berkaitan dengan sumber daya manusia bisa dilihat dari segi kepemimpinan. Pimpinan SMA Setia Dbarma Pekanbaru bernama Drs. $\mathrm{H}$. Bachtiar. Dilihat dari kepemimpinannya, beliau adalah kepala sekolah yang sangat mengedepankan kedisiplinan, enerjik, cerdas, dan senantiasa berusaha memajukan pendidikan terutama di lingkungan SMA Setia Dharma Pekanbaru.

Pimpinan sekolah bertugas dan bertanggung jawab penuh tentang keberhasilan sekolahnya. Untuk itu seorang kepala sekolah dapat menyusun kegiatan proses belajar mengajar dan seorang kepala sekolah berfungsi sebagai pimpinan, educator, manager, administrator, supervisor, dan inovator. Demi tercapainya keberhasilan yang diinginkan, kepala sekolah dibantu oleh para wakil-wakil kepala sekolah dari setiap bidang yang masing-masing mempunyai tugas.

Tugas Wakil Kepala Sekolah Bidang Kurikulum ; Pembagian tugas guru yaitu menyusun jadwal kegiatan lainnya (IMTAQ, Terobosan dan lain-lain). menyusun program KBM, mengumpulkan dan memeriksa perangkat pembelajaran 
guru, melayani pengawas dinas yang berurusan dengan akademik, menggantikan kepala sekolah apabila berhalangan hadir atau dinas luar, dan lain-lain berkaitan dengan akademik.

Tugas Wakil Kepala Sekolah Bidang Kesiswaan ; penyusunan kelas pembagian panitia Orientasi Siswa Baru, penjelasan tata tertib. mengelola dan membina organisasi sekolah (OSIS), membentuk Kelompok K3 setiap kelas, membimbing seluruh kegiatan siswa, dan menangani siswa yang bermasalah

Tugas Wakil Kepala Sekolah Sarana dan Prasaran; melayani sarana kebutuhan guru dan siswa, sebagai koordinator piket guru, mengelola K3 Sekolah dan Kelas dan lain-lain.

Tenaga pengajar yang terdapat di SMA Setia Dharma Pekanbaru berjumlah 23 orang. Sedangkan Tenaga adminstrasi yang terdapat di SMA Setia Dharma Pekanbaru berjumlah 2 orang, yaitu Suwito sebagai Kepala Tata Usaha (TU) dan Oslan Dianto sebaga staf adminstrasi. Pustakawan di SMA Setia Draharma Pekanbaru berjumlah 1 orang yakni Dra. Haswinta Riora.

Laboratorium yang terdapat di SMA Setia Dharma Pekanbaru berjumlah dua buah yang terdiri dari satu labor Kimia/Fisika/Biologi dan satu labor komputer (dilengkapi jaringan internet). Kepala labor Kimia, adalah Fitriati, S.Si.Kepala labor Biologi adalah Ir. Abrina Ade. Kepala Labor Fisika, Rima Melati dan Kepala labor komputer adalah Yuni Yarlis, S.Pd.

Siswa SMA Setia Dharma Pekanbaru Tahun Ajaran 2015/2016 berjumlah 160 siswa. Dari 160 siswa tersebut dibagi ke dalam 6 kelas, yaitu kelas X berjumlah 2 kelas, Kelas XI berjumlah 2 kelas, dan Kelas XII berjumlah 2 kelas.

Sarana dan Prasarana yang terdapat di SMA Setia Dharma Pekanbaru dapat dikategorikan cukup lengkap, seperti tersedianya Musholla, Labor, Ruang Kepala Sekolah, Ruang Majelis Guru,
Ruang TU, Ruang UKS, Aula Terbuka, WC Guru dan WC siswa, Kantin, Parkiran Kendaraan, Pos Satpam, dan juga fasilitasfasilitas olahraga seperti lapangan basket.

\section{Implementasi Pendidikan Akhlak Mulia di SMA Setia Dharma Pekanbaru.}

Guru merupakan pendidik profesional yang akan membantu peserta didik dalam mencerdaskan intelektual, emosional dan spritualnya. Untuk itulah sosok seorang guru akan berpengaruh kepada keberhasilan pendidikan akhlak mulia. Pengaruh inilah yang semestinya di maksimalkan oleh guru dalam funginya sebagai seorang pendidik dan tidak hanya sebagai pengajar.

Berdasarkan hasil temuan penelitian dapat dijelaskan sebagai berikut: Pelaksanaan Pendidikan Akhlak mulia jika ditilik dari aspek keteladanan dapat di ungkapkan dari keteladanan dalam ibadah seperti yang disebutkan oleh kepala sekolah bahwa hanya sebagian guru yang melaksanakan sholat tepat pada waktunya, dan berkaitan dalam memandang konsep ibadah dalam kehidupan sehari-hari kepala sekolah dan sebahagian besar guru menyatakan sangat penting dan wajib terutama karena ibadah adalah merupakan bentuk penghambaan kepada Allah, ibadah pun sudah di rasakan oleh kepala sekolah dan para guru sebagai suatu kebutuhan, namun berkaitan dengan sholat zuhur berjamaa'ah hanya di lakukan kadangkadang saja seperti yang diungkapkan oleh kepala sekolah karena belum adanya peraturan yang tertulis tentang wajibnya sholat berjama'ah di sekolah,

Berkaitan dengan keteladanan bermurah hati misalnya bersedekah ketika dalam keadaan lapang ataupun sempit, kepala sekolah dan para guru di SMA Setia Dharma sudah melakukannya dan ada yang mengatakan harus disertai dengan keikhlasan. Selain itu kepala sekolah juga mengungkapkan bahwa membantu keluarga yang terdekat 
maupun jauh dengan memberikan zakat mal dan infak.

Kepala sekolah juga mengungkapkan adalah suatu hal yang bagus untuk menyantuni anak yatim bahkan ada guru yang menyatakan bahwa itu adalah suatu kewajiban umat Islam. Berkaitan dengan keterkaitan ibadah sholat dan zakat kepala sekolah dan para guru sudah menyadari tentang pentingnya ibadah tersebut.

Keteladanan kerendahan hati, dalam hal ini kepala sekolah mengungkapkan bisa menerima apabila ada yang mengkritik keputusannya namun terkadang ada juga merasa kurang senang. Diantara para guru ada yang menyatakan bisa menerima ada juga yang tidak senang apabila keputusannya dikritik. Berkaitan tentang adanya perbedaan pendapat dalam menyikapi suatu masalah kepala sekolah mengatakan bahwa itu adalah suatu hal yang wajar untuk menetapkan keputusan yang lebih baik, sebahagian besar para guru juga menyatakan bahwa mesti menerima dan berlapang dada.

Keteladanan kesantunan, ketika bertemu kepala sekolah dan para guru menyatakan terkadang ada mengucapkan salam karena dengan mengucapkan salam hati terasa nyaman. Kepala sekolah dan para juga berupaya untuk membiasakan hal tersebut kepada siswa. Selain itu mengajarkan adab kepada peserta didik adalah suatu hal yang sanat perlu.

Keteladanan keberanian, kepala sekolah dan para guru mengungkapkan akan membela nilai-nilai kebenaran meskipun tidak ada yang setuju, dan memberikan pengertian kepada siswa untuk tidak takut berkata benar meskipun diancam oleh temannya.

Keteladanan dalam memegang akidah, kepala sekolah dan para guru menyatakan bahwa perlu untuk memahami konsep akidah Islam yang lurus dan mengajarkan serta menerapkannya kepada siswa dan berkaitan dengan aliran-aliran keagamaan yang bisa mengganggu akidah umat Islam kepala sekolah dan para guru menyatakan bahwa harus istiqomah dengan agama Islam dan berpegang teguh pada al-qur'an dan sunnah. Selain itu kepala sekolah dan para guru juga telah berupaya agar siswa tidak terpengaruh dengan budaya-budaya di luar Islam.

Untuk aspek pendidikan dengan pembiasaan kepala sekolah dan para guru menyatakan sudah berusaha untuk melakukan kebiasaan-kebiasaan yang baik sehingga bisa ditiru oleh siswa seperti cara belajar yang baik, mendisiplinkan siswa dalam segala hal, dan membiasakan siswa untuk mau melaksanakan ibadah dan selalu bertanggung jawab dalam segala perbuatannya.

Berkaitan dengan aspek pendidikan dengan nasehat kepala sekolah dan para guru telah mengungkapkan bahwa pendidikan dengan nasehat itu penting dan selalu berupaya untuk mengajak siswa untuk berbuat kebaikan seperti sholat berjama'ah dan membaca al-qur'an sebelum memulai belajar.

Upaya kepala sekolah dan guru agar siswa bisa menerima nasehat mereka adalah dengan mencontohkan perbuatan tersebut, dan juga terkadang dengan menceritakan kisah-kisah Nabi dan orangorang shaleh dan juga ada terkadang menyebutkan ayat al-qur'an dan hadis Nabi dalam memberikan nasehat.

Berkaitan dengan aspek pendidikan dengan perhatian kepala sekolah dan para guru sudah menyadari bahwa pendidikan dengan perhatian akan bisa memperbaiki akhlak siswa menjadi lebih baik, bahkan kepala sekolah dan para guru berupaya mendidik siswa seperti anak sendiri. Upaya perhatian dalam bentuk pembinaan akidah, akhlak mulia serta spritual dan sosial.

Berkaitan dengan aspek pendidikan dengan memberikan hukuman, kepala sekolah dan guru menyatakan hukuman yang mendidik adalah cara yang cukup efektif dalam dalam merubah kebiasaan 
buruk menjadi baik, dan adanya peraturan yang mengikat di sekolah untuk keefektifan hukuman dan diupayakan menghukum dengan kelembutan dan kasih. sayang .

\section{Faktor Pendukung dan dan Penghambat}

Keberhasilan kegiatan tidak telepas dari faktor pendukung dan penghambat, begitu juga dengan implementasi pendidikan akhlak ini.

Berdasarkan temuan hasil penelitian dapat diketahui bahwa faktor pendukung dari terlaksananya pendidikan akhlak mulia di SMA Setia Dharma pekanbaru adalah; visi dan misi sekolah yang sudah menggambarkan tentang akhlak mulia, dan semua komponen sekolah sudah mengetahui tentang visi misi sekolah, dari hasil observasi visi dan misi telah di pajang di lingkungan sekolah sehingga semua warga sekolah sudah bisa membacanya. Berdasarkan keterangan kepala sekolah dan juga dipertegas oleh guru bahwa sebagian mata pelajaran juga sudah dikaitkan dengan pendidikan akhlak mulia, adanya kegiatan IMTAQ di hari jum'at pagi, adanya kerjasama semua komponen yang di sekolah yaitu guru, kepala sekolah, pegawai, komite sekolah, satpam dan yang lainnya.

Faktor penghambat dari terlaksananya pendidikan akhlak mulia di SMA Setia Dharma yaitu musholla yang tidak memadai hanya $8 \times 9 \mathrm{~m}$, dan alokasi dana yang belum mencukupi untuk kegiatan keagamaan yang lebih maksimal, sehingga pihak sekolah melakukan kerja sama dengan orang tua dan komite sekolah.

\section{PEMBAHASAN}

Pendidikan akhlak mulia di SMA Setia Dharma sudah terlaksana namun belum maksimal ini di lihat dari sudah berupayanya kepala sekolah dan guru menunjukkan keteladanan dalam beribadah serta bersikap dan perilaku di lingkungan sekolah sehingga bisa di tiru oleh peserta didik. Selain itu pembiasaanpembiasaan yang baik juga sudah dilaksanakan di sekolah tersebut.

Menurut kepala sekolah kegiatan IMTAQ sudah dilakukan setiap jum'at pagi dan adanya program membaca Al-Qur'an sebelum pelajaran di mulai. Namun menurut peneliti ini belum memadai karena pentingnya pendidikan akhlak mulia ini, suasana keagaaman perlu ditampakkan seperti adanya pamlet yang menunjukkan tentang keutamaan sholat misalnya, ataupun bimbingan tentang betapa pentingnya fungsi agama dalam kehidupan manusia.

Sebagaimana yang diungkapkan oleh Marzuki membangun karakter siswa secara utuh harus memperhatikan dua dimensi kehidupan manusia, yaitu dimensi vertikal dalam rangka akhlak mulia terhadap Allah SWT dan dimensi horizontal dalam rangka berhubungan dengan sesama manusia. Oleh karena itu, pendidikan akhlak mulia siswa melalui kegiatan-kegiatan keagamaan menjadi sangat penting, di samping melalui pembiasaan-pembiasaan nilai-nilai kebaikan yang bersifat universal.

Sekolah sebaiknya memiliki buku panduan pengembangan kultur akhlak mulia yang komprehensif agar menjadi pedoman yang baku dalam pengembangan kultur akhlak mulia di sekolah. Buku ini dapat dijadikan sebagai pedoman yang bisa dibaca dan dipahami oleh semua komponen sekolah yang akhirnya dapat dipraktikkan dengan mudah di sekolah.

Sebagai kelengkapan perangkat untuk kelancaran pengembangan kultur akhlak mulia, perlu juga dilakukan pengawasan dan evaluasi terhadap program pembangunan kultur akhlak mulia yang dilakukan di sekolah agar dapat diambil sikap yang tepat (Marzuki, 2015: 106-110).

Perubahan dalam perilaku menjadi lebih baik juga di dukung oleh sarana dan 
prasarana yang lengkap, namun di SMA Setia Dharma musholla yang ada belum memadai, satu musholla digunakan oleh tiga sekolah SMP Setia Dharma, SMA Setia Dharma dan SMK Setia Dharma. Ini tentu tidaklah cukup menampung warga sekolah untuk melaksanakan sholat berjamaa'h.

Pendidikan akhlak mulia ini merupakan poros kemajuan bangsa Indonesia karena suatu bangsa akan maju apabila masyarakatnya memiliki hubungan yang baik dengan Allah dan sesama manusia, disinilah kunci peradaban, tidak hanya dilihat dari semakin bagusnya gedung-gedung dibangun tetapi secara akhlaknya merosot. Namun yang diharapkan adalah keseimbangan antara kesuksesan dalam bidang teknologi dan juga memiliki akhlak yang mulia

\section{PENUTUP}

Kepala sekolah dan para guru sudah berupaya mengimplementasikan pendidikan akhlak mulia kepada para peserta didik baik dari aspek pendidikan keteladanan, pembiasaan, perhatian, pemberian nasehat, dan hukuman yang mendidik.

Faktor pendukung dari kepala sekolah yang berupaya mensosialisasikan visi dan misi sekolah kepada warga sekolah dan adanya kerjasama antara kepala sekolah dan komponen lainnya. Faktor penghambat masih kurang memadainya musholla dan alokasi dana untuk kegiatan keagamaan.

Rekomendasi untuk kepala sekolah agar semakin berupaya untuk menciptakan suasana keagamaan di sekolah sehingga pendidikan akhlak mulia ini bisa semakin berhasil. Bagi guru pada semua mata pelajaran, hendaknyalah mengaitkan mata pelajaran yang diajarkannya dengan pendidikan akhlak mulia, karena pendidikan akhlak mulia ini tidaklah hanya tanggung jawab guru Pendidikan Agama Islam, Bahasa
Indonesia, PPkN, dan guru BK tetapi adalah tugas semua guru. Bagi yayasan, diharapkan untuk menyediakan musholla yang memadai untuk semua warga sekolah, karena musholla dn mesjid merupakan tempat pendidikan yang utama. Bagi Dinas Pendidikan, untuk lebih memperhatikan pendidikan akhlak mulia di sekolah-sekolah umum, karena sangat pentingnya pendidikan akhlak mulia ini dalam diri peserta didik dan masyarakat muslim pada umumnya.[] 


\section{DAFTAR RUJUKAN}

Al-Abrasyi, Muhammad Athiyah. AlTarbiyah al-Islamiyah wa Falaasifatuha, Beirut: Dar-al-Fikr, tt.

Al-Barik, Haya Binti Mubarok. Mausu'ah al-Mar'atul Muslimah, terj. Amir Hamzah Fachrudin, Ensiklopedi Wanita Muslimah", Jakarta : Darul Falah, Cet. IV, 1998.

Al-Bashry, Abu al-Hasan Ali bin Muhammad bin Habib al-Mawardi. Adab al-Dunya wa al-Diin, Kairo : Dar al-Fikr, tt.

Al-Ghazali, Imam. Ihya' ulum al-Din, Kairo: al-Mashad al-Husain, tt.

Al-Jumbulati, Ali, alih bahasa: H.M. Arifin, Perbandingan Pendidikan Islam, Jakarta: PT. Rineka Cipta, 1994.

Amin, Ahmad. Etika (Ilmu Akhlak), alih bahasa: Farid Ma'ruf, Jakarta: PT. Bulan Bintang, 1995.

Arikunto, Suharsimi. Prosedur Penelitian Pendekatan Praktik, Jakarta: Rineka Cipta, 1996.

Asmaran AS, Pengantar Studi Akhlak, Jakarta: PT. Raja Grafindo Persada, 2002.

Az-Za'balawi, M. Sayyid Muhammad. Pendidikan Remaja antara Islam dan Ilmu Jiwa, Jakarta: Gema Insani, 2007.

Bungin, Burhan. Metode Penelitian Kualitatif: Aktualisasi Metodologis ke Arah Ragam Varian Kontemporer, Jakarta: P.T. Raja Grafindo Persada, 2001.

Daradjat, Zakiah. Membina Nilai-nilai Moral di Indonesia, Jakarta: PT. Bulan Bintang, 1976.

Djanika, Rachmat. Sistem Etika Islami (Akhlak Mulia), Jakarta: Pustaka Panji Mas, 1996.

Emzir, Metodologi Penelitian Kualitatif Analisis Data, Jakarta : PT. Grafindo Persada, 2012.

Langgulung, Hasan. Azas-azas Pendidikan Islam, Jakarta : PT. Al-Husna Zikra, Edisi revisi, 2000.
Ma'luf, Luis. Kamus al-Munjid, BeirutL alMaktabah al-Katulikiyah, tt.

Marzuki, Pendidikan Karakter Islam, Jakarta : Bumi Aksara, 2015.

Miskawih, Ibn. Menuju Kesempurnaan Akhlak, Bandung: Mizan, 1997.

Nata, Abuddin. Kapita Selekta Pendidikan Islam, Isu-isu Kontemporer tentang Pendidikan Islam, Jakarta : PT. Raja Grafindo Persada, 2012.

Quthb, Muhammad. t.t, Terj. Salman Harun "Sistem Pendidikan Islam", Bandung: Ma-arif, 1993.

Ramayulis dan Samsul Nizar, Filsafat Pendidikan Islam Telaah Sistem Pendidikan dan Pemikiran Para Tokohnya, Jakarta: Kalam mulia, 2009.

Shihab, Quraish.Wawasan al-Qu'ran, Bandung: Mizan, 2007.

Sugiyono, Metode Penelitian Kuantitatif, Kualitatif dan R\&D, Jakarta: Alfabeta, 2012.

Sujadi, Metodologi Penelitian Pendidikan, Jakarta: Rineka cipta, 2003.

Suryanto dan Djihad Hisyam, Pendidikan di Indonesi Memasuki Millennium III,Yogyakarta: Adicita Karya Nusa, 2000.

Syahidin, Metode Pemdidikan Qurani, Teori dan Aplikasi, Jakarta: Misaka Galiza, 2001.

Ulwan, Abdullah Nashih. Tarbiyah alAulad fi al-Islam, Kairo : Dar al-salam, 2011.

Ya'kub, Hamzah. Etika Islam, Bandung: CV. Diponegoro, 1991. 